\title{
Properties of Cellulose Sheets Modified with Potassium-Humate and Copper (II)-Sulfate
}

\author{
A. TóTH ${ }^{1}$, K. HALÁSZ² \\ 1University of Sopron, Simonyi Károly Faculty, Institute of Wood Based Products and Technologies, Sopron \\ toth.annamaria@phd.uni-sopron.hu \\ ${ }^{2}$ University of Sopron, Simonyi Károly Faculty, Institute of Wood Based Products and Technologies, Sopron \\ halasz.kata@uni-sopron.hu
}

Abstract. Throughout our research we have made potassium-humate from brown coal of Dudar. With potassiumhumate and copper(II)-sulfate we made test sheets of linter cellulose fibers. The surface energy, surface wettability, CIE Lab color-coordinates changing, bending resistance and tensile strength of the produced test sheets has been examined. There was no big difference in the different samples during surface energy and wettability testing. Examination of mechanical properties suggests that potassium-humate content increases bending resistance of the test sheets. The bending resistance of samples increased by 32\%, 100\% and 336\% compared to the control test sheets while adding potassium-humate.

Keywords: Potassium-humate, cellulose, copper(II)-sulfate, mechanical properties, surface free energy, furface wettability

\section{Introduction}

The humic acids - humic acid, fulvic acid and himatomelanic acid belong here - are natural substances with overwhelmingly vegetal origin [1]. The fossil forms of the humic matters formed in the geolic ages and under the geolic effects in other former recent forms buried by stratifications. The compounds that formed them also can be found in different quantities (depending of the circumstances) in mineral coals [2]. Their extraction happens with the most modern technologies from vegetal sediments (eg. peat).

The humic acids are complex polymers built up from aromatic heterocyclic and isocyclic rings attached to each other with covalent bond directly. The side chains attaching to the backbone chain have acid character (fenol-OH, alcoholic- $\mathrm{OH}$, carbonic-OH and carboxylic-OH) or basic character (imino and amino character) [3] [4]. There is a genetic context between soil humic acids and coal humic acids, their chemistry construction stands very close to each other. The latter ones are very important in terms of soil enrichment and cultivation, their usage will be intensify in the field of bio cultivation [5]. Besides their role in soil, the humic acids are bilogically active substances on all areas of science, they may get role even in the fields of medicine and vetenary medicine. 
Alkali humates - water-soluble salts of the humic acids - are produced from brown coal, lignite and peat with the help of alkaline extraction. The extraction results in potassium-humate if potassium hydroxide is used as extractant and sodium-humate if sodium hydroxide. The brown coal of Dudar (Hungary) has high potential in humate production since it has remarkably high humic acid content [6] [7] [8]. These kind of alkali-humates are connected with metals well. The aromatic carboxil- and hyrdoxil groups found in humate can make a metastable complex with metals and other cations [9] [10] [11].

In the course of paper-making cellulose fibres are treated with aluminium sulphate, which increases the strenght of paper and destroys the harmful microorganisms [12]. In our study we prepared a handsheets with the addition of copper(II)-sulphate instead of aluminium-sulphate, which dissolves in water and has acidic pH similarly to aluminium-phosphate. The antibacterial characterictics of copper(II)-sulphate is better contrary to aluminium-sulphate. Alkali humate is well bonded to metals and positive ions. Immobilization of copper on cellulose fibres can provide antimicrobial characteristics to the cellulose sheet as reported by Llorens et al. (2012), Booshehri et al. (2015), whilst humate can presumably increase the adsorbed copper onto the fibres [10] and offer gas absorption properties[15] .

In the course of our research, potassium-humate was added to make test sheets containing copper ions with different content of potassium-humate (weight/weight \%). Our aim was to examine the effect of $\mathrm{CuSO}_{4}$ and potassium-humate prior the microbial and gas absorption tests to see how these additives changes the mechanical, colour, surface properties and air resistance of the cellulose sheet.

\section{Materials and Methods}

\subsection{Materials}

Brown coal from Dudar were supplied by Agroterm Kft. (Hungary),

KOH (Mw=56.11 g/mol, $2.13 \mathrm{~g} / \mathrm{ml})($ Molar Chemicals Kft., Hungary,)

CuSO4 (M=249.68 g/mol, $2.28 \mathrm{~g} / \mathrm{ml}$ ) (Molar Chemicals Kft., Hungary)

Cellulose (primer linter cellulose)

\subsection{Methods}

\subsubsection{The production of alkali humate}

The production of alkali humate was based on patent no. HU 209 134. According to the patent we mixed $100 \mathrm{~g}$ dudar coal with $50 \mathrm{ml} 5 \mathrm{M} \mathrm{KOH}$ solution, mixed it for 3 hours with a magnetic stirrer. The mixture was then elutriated at room temperature for one night and fractioned the next day with a centrifuge for 10 minutes at 2400rpm. The treatment of coal with a solution of $\mathrm{KOH}$ gives soluble potassium-humate $(\mathrm{PH})(1)$ :

$$
\mathrm{Hum}(\mathrm{COOH})_{n}+n \mathrm{KOH} \rightarrow \mathrm{Hum}(\mathrm{COOK})_{n}+n \mathrm{H}_{2} \mathrm{O}
$$




\subsubsection{The preparation of test sheets}

Cellulose fibers were cured for 40 minutes in order to achieve adequate fibrillation in a Dutch mill. The drainability of the fibers were measured according to MSZ EN ISO 5267-1: 1999 as 48 SR $^{\circ}$.

Preparation of alkali humate test sheets was made based on HU 207682 Patent no, with changes. To the cellulose fibers (moving on a magnet stirrer), CuSO4 was added until the suspension had a pH of 4.5. After standing at room temperature for one day, the potassium-humate solution was added. It was stirring for 20 minutes at $200 \mathrm{rpm}$. Different proportions of potassium-humate mixtures were prepared from the suspension of the fiber, and test sheets were prepared on Erst Haage D-45476 type sheet forming.

The composition of the handsheets are listed in Table 1.

\begin{tabular}{cc}
\hline & Content (weight rate) \\
\hline Test sheet 1 & Control \\
Test sheet 2 0.1 & Copper-cellulose : potassium- \\
humate & $1: 0.25$ \\
Test sheet 3 & Copper-cellulose : potassium- \\
& humate \\
& $1: 0.5$ \\
Test sheet 4 & Copper-cellulose : potassium- \\
& humate \\
Test sheet 5 & Copper-cellulose \\
\hline Table 1: Different test sheets compositions
\end{tabular}

Before each test, the samples were conditioned at $23^{\circ} \mathrm{C}$ and $50 \% \mathrm{RH}$ for at least $24 \mathrm{~h}$.

\subsubsection{Colour difference of test sheets}

Test sheets were evaluated using an X-Rite 500 spectrodensitometer from X-Rite, USA. The values presented here are the $\mathrm{b}^{*}$ values, $\mathrm{a}^{*}$ values, $\mathrm{L}^{*}$ values and $\Delta \mathrm{E}$ values.

$\mathrm{b}^{*}$ values correspond to the blue-yellow colour axis, $\mathrm{a}^{*}$ values correspond to the red-green colour axis ant the $L^{*}$ values correspond to the lightness axis in the CIELAB colour space (higher $b^{*}$ value indicating a more yellow). CIELAB colour difference $(\Delta \mathrm{E})$ of the test sheets were calculated using the following equation:

$$
\Delta \mathrm{E}=\sqrt{\left(\mathrm{L}_{\mathrm{i}}^{*}-\mathrm{L}^{*}\right)^{2}+\left(\mathrm{a}_{\mathrm{i}}^{*}-\mathrm{a}^{*}\right)^{2}+\left(\mathrm{b}_{\mathrm{i}}^{*}-\mathrm{b}^{*}\right)^{2}}
$$

$\mathrm{L}_{\mathrm{i}}^{*}$ : L values of test sheet

$\mathrm{L}^{*}$ : L reference values

$\mathrm{a}_{\mathrm{i}}^{*}$ : a values of test sheet 
$a^{*}$ : a reference values

$\mathrm{b}_{\mathrm{i}}^{*}: \mathrm{b}$ values of test sheet

$b^{*}$ : b reference values

\subsubsection{Surface wettability and Surface free energy}

For contact angle measurements PG-X Goniometer was used, 10 measurements were performed with a measuring drop of $5 \mu \mathrm{l}$, and the contact angle was measured at $0.031 \mathrm{sec}$ after the release of the droplet. Test liquid was (analytical clear) two-times distilled water.

Apparent contact angles for liquid probes on test sheets were measured using a PG-X Goniometer. A 5 $\mu \mathrm{l}$ liquid drop ( $3 \mu \mathrm{l}$ for DIM) was delivered to the surface of the sample. At least 10 measurements were taken for each liquid probe. The surface energy of the test sheets were calculated using the following equation:

$$
\sqrt{\gamma_{S}^{D} * \gamma_{I}^{D}}+\sqrt{\gamma_{S}^{P} * \gamma_{I}^{P}}=\frac{\gamma_{I}(\cos \theta+1)}{2}
$$

With $\gamma_{\mathrm{S}} \mathrm{D}$ : dispersive component of the surface energies of the solid $\left[\mathrm{mJ} / \mathrm{m}^{2}\right]$

$\gamma_{1}{ }^{D}$ : dispersive component of the surface energies of the liquid $[\mathrm{mN} / \mathrm{m}]$

$\gamma_{S^{P}}$ : polar component of the surface energies of the solid $\left[\mathrm{mJ} / \mathrm{m}^{2}\right]$

$\gamma_{\mathrm{I}}^{\mathrm{P}}$ : polar component of the surface energies of the liquid $[\mathrm{mN} / \mathrm{m}]$

$\gamma_{\mathrm{I}}$ : surface energies of liquid $[\mathrm{mN} / \mathrm{m}]$

$\theta$ : contact angle $\left[{ }^{\circ}\right]$

\subsubsection{Mechanical properties}

Bending force was measured based on ISO 2493. The test was performed on a Büchel Stiffness Tester, with $15^{\circ}$ bending angle, $50 \mathrm{~mm}$ test span length and $38 \mathrm{~mm}$ sample width. A mean value was calculated from 10 measurements.

To determine the tensile strength and elongation at breakpoint of the films tensile test was performed by using an Instron 3345 tensile tester. Five-five samples were fixed between the grips of the device with a gauge length of $36 \mathrm{~mm}$ then $20 \mathrm{~mm} / \mathrm{min}$ crosshead speed was applied. The width of the samples was $10 \mathrm{~mm}$. The measurements were conducted at $23 \pm 2{ }^{\circ} \mathrm{C}$, with the relative humidity of 50 $\pm 5 \%$.

The compressive strength, which indicates the maximum compressive force per unit width of cellulose fiber sheets without failing, were determined according to MSZ EN ISO 9895 using short-span (0.7 $\mathrm{mm}$ ) compressive tester. The width of the sample was $15 \mathrm{~mm}$. The compressive strength was expressed in $\mathrm{kN} / \mathrm{m}$. 


\subsubsection{Air resistance (Gurley method)}

The necessary time to pass $100 \mathrm{ml}$ air through the handsheets was determined by Gurley method (based in ISO 5636-5), with a L\&W Gurley densometer. The air resistance was measured on the opposite side of the sieve side and expressed in $\mathrm{s} / 100 \mathrm{ml}$ of air.

\section{Results}

\subsection{Colour difference of test sheets}

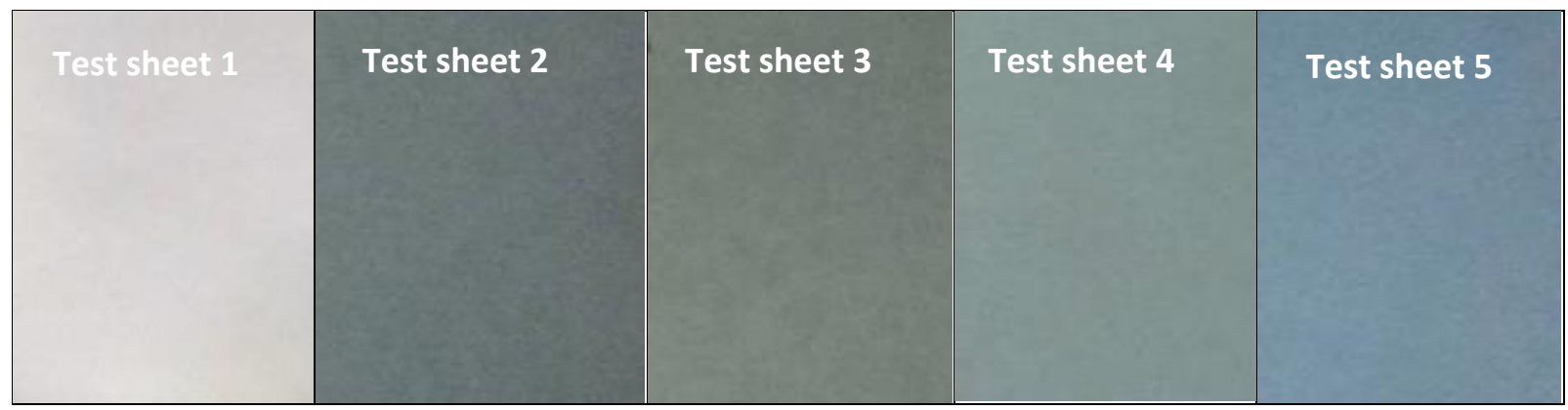

Figure 1: Different colours of tests sheets

\begin{tabular}{lccccc} 
& $\mathrm{L}$ & $\mathrm{a}$ & $\mathrm{b}$ & $\Delta \mathrm{E}^{*}$ & $\Delta \mathrm{E}^{* *}$ \\
\hline Test sheet 1 & $92.75 \pm 0.22$ & $-1.34 \pm 0.41$ & $3.52 \pm 0.21$ & & \\
Test sheet 2 & $65.9 \pm 0.15$ & $-3.05 \pm 0.26$ & $3,97 \pm 0.33$ & 17.67 & \\
Test sheet 3 & $66.54 \pm 0,51$ & $-3.59 \pm 0.34$ & $6.61 \pm 0.46$ & 26.48 & 9.14 \\
Test sheet 4 & $75.08 \pm 0.22$ & $-10.65 \pm 0.77$ & $1.92 \pm 0.75$ & 28.48 & 8.50 \\
Test sheet 5 & $83.86 \pm 0.41$ & $-18.46 \pm 0.50$ & $-4.46 \pm 0.78$ & 20.87 & \\
\hline
\end{tabular}

Table 2: CIELab measurement results of different test sheets

*colour difference of sheets compared to unmodified cellulose sheet (Test sheet 1 )

** colour difference of potassium-humate containing sheets compared to each other

The results of CIE Lab color measurement are summarized in Table 2. Examining luminance $\left(\mathrm{L}^{*}\right.$ ) results, it can be observed that samples of potassium-humate (TS 2-4) have lower luminance values, i.e., the samples are darker than those without humate (TS $1 ; 5)$.

This means that humate can form a chemical bond on the surface of cellulose fibers, thus sticking to it. The $\mathrm{a}^{*}$ value of the red-green axis values the samples. The lower this value, the greener the pattern. The test sheet (TS 5) value is -18.46 , while the other test sheets are $-10.65,-3.59,-3.05,-1.346$, which indicates that the test sheet 5 has a lot more green color, this difference is also visible to the naked eye (Figure 1). From the samples containing copper-sulphate (TS 2-5) test sheet 5 does not contain potassium-humate. Because of the intense color of copper-sulphate, test sheet 5 contains more green colors compared to other samples. $b^{*}$ is the value of the blue-yellow axis, the higher this value the more yellow is found in the sample. Test sheet 2, 3 and 4 have more yellow than control test sheet (TS 1). Test sheet 5 is much lighter than the other tested samples. The bluish color of copper-sulphate dominates in test sheet 5 . Compared to control test sheet (TS 1), the value of $\Delta \mathrm{E}$ was 26.91 for sample test sheet 2, 20.05 for test sheet 3, 20.05 for test sheet 4, and 20.88 for test sheet 5 (Table 2.). The 
changes in $\Delta \mathrm{E}$ are classified as "very intensive" color difference (Table 3) [16] [21] compared to the control sample. Compared to the $\Delta \mathrm{E}$ values for $10 \mathrm{w} \%$ potassium-humate (TS 2). The $\Delta \mathrm{E}$ values of the samples are increasing containing humate. $25 \mathrm{w} \%$ potassium-humate sample (TS 3) $\Delta \mathrm{E}: 9.14,50 \mathrm{w} \%$ sample containing potassium-humate (TS 4) $\Delta \mathrm{E}$ is 8.5 .

\begin{tabular}{cc} 
Colour difference $(\Delta \mathrm{E})$ & Colour variation estimation \\
\hline & \\
$\Delta \mathrm{E} \leq 0.2$ & undiscernible \\
$0.2<\Delta \mathrm{E} \leq 0.5$ & Very light \\
$0.5<\Delta \mathrm{E} \leq 1.5$ & light \\
$1.5<\Delta \mathrm{E} \leq 3.0$ & clear \\
$3.0<\Delta \mathrm{E} \leq 6.0$ & Very clear \\
$6.0<\Delta \mathrm{E} \leq 12$ & intensive \\
$12<\Delta \mathrm{E}$ & Very intensive \\
\hline
\end{tabular}

Table 3: Correlation between sense perception and colour difference ( $\Delta E$ ) according to Straze et al. (2008) and Jirouš and Ljuljka (1999)

\subsection{Surface wettability and surface energy}

The surface energy of sheets was characterized and the dispersion $(\gamma \mathrm{SD})$ and polar $(\gamma \mathrm{SP})$ components of surface free energy were determined by contact angle measurements against water and diiodomethane.

All test sheets has water contact angles of about $40^{\circ}$, indicating good wetting property and high hydrophilicity [22]. The contact angles against diiodomethaneis around $34^{\circ}$ (Table 4). The additives did not changed the hydrophilicity of the cellulose fibers.

Based on the contact angle values, the surface free energy of test sheets was calculated. Results prove that the total surface free energy values hardly differ in different test sheets at $0,1 \mathrm{~s}, 69.16-84.9 \mathrm{~m} \mathrm{Nm}$ 1 , at $5 \mathrm{~s} 46.33-63.05 \mathrm{~m} \mathrm{Nm}-1$ ( Figure 2). The total surface free energy values are nearly the same for the test sheets derived from different concentrations of potassium-humate.

The sheets can be easily printed and glued as the surface energy values are within 40-70 m Nm-1 [23] , which means that test sheets are still in the range.

\begin{tabular}{|l|l|r|r|r|r|}
\hline Characteristics & Type of test sheets & \multicolumn{4}{|c|}{ Concentration of potassium-humate (\%) } \\
\hline & & 0 (TS 5) & 10 (TS 2) & 25 (TS 3) & 50 (TS 4) \\
\hline \multirow{2}{*}{ Water contact angle $\left(^{\circ}\right)$} & Cellulose (TS 1) & $49 \pm 10$ & & & \\
\cline { 2 - 6 } & Copper-cellulose & $40.96 \pm 8$ & $32.96 \pm 8$ & $33.43 \pm 7.5$ & $42.61 \pm 9.3$ \\
\hline \multirow{2}{*}{$\begin{array}{l}\text { Diiodomethane contact } \\
\text { angle }\left(^{\circ}\right.\end{array}$} & Cellulose (TS 1) & $35.9 \pm 0.47$ & & & \\
\cline { 2 - 6 } & Copper-cellulose & $32.6 \pm 2$ & $32.9 \pm 4$ & $35.73 \pm 3.75$ & $36.48 \pm 5.5$ \\
\hline
\end{tabular}

Table 4: Contact angles agains water and diiodomethane of liner-cellulose with different concentration of potassium-humate at $0.031 \mathrm{~s}$ 


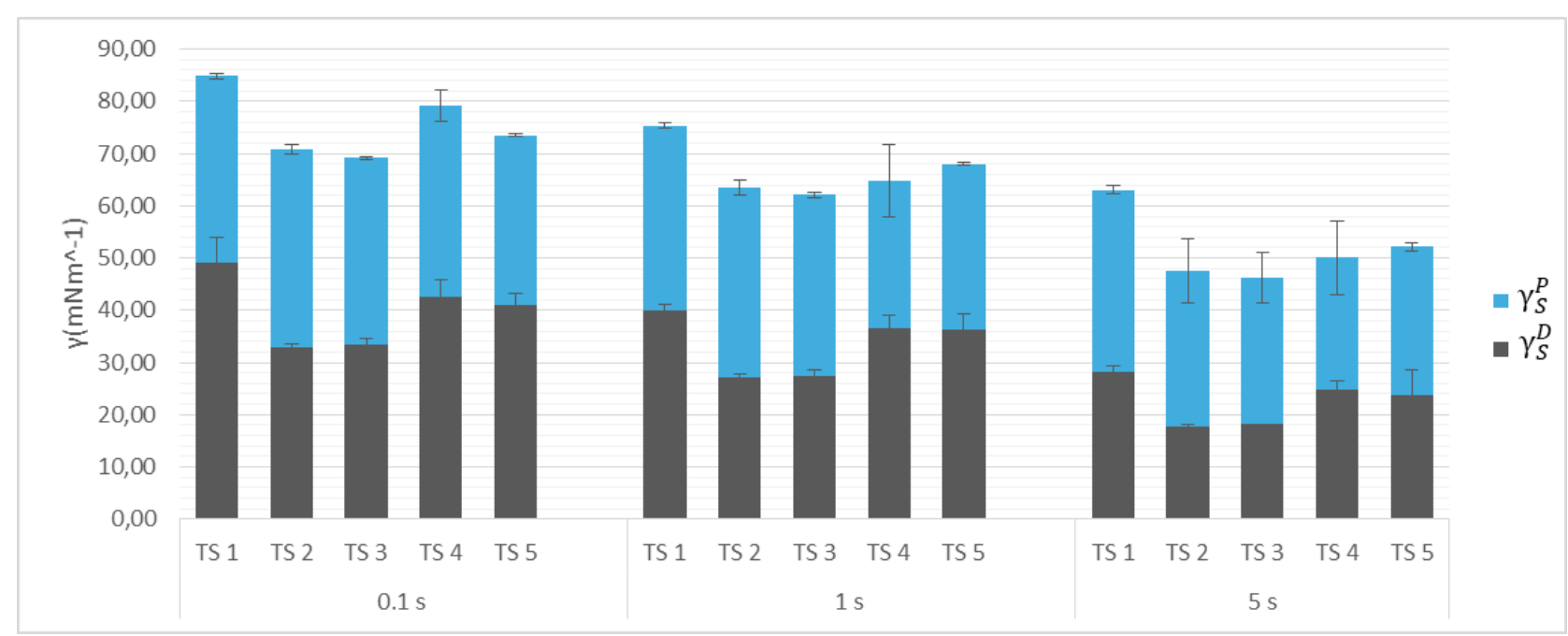

Figure 2: surface free energy $\left(\gamma_{S}\right)$ with its components dispersive $\left(\gamma_{S}^{D}\right)$ and polar $\left(\gamma_{S}^{P}\right)$ for all test sheets

\subsection{Mechanical properties}

The modification of cellulose fibres with $\mathrm{CuSO}_{4}$ did not affect the flexibility remarkably. However, adding humate the bending resistance was remarkably increased (Table 5). 10 and $25 \mathrm{w} \%$ humate doubled the bending resistance, whilst $50 \mathrm{w} \%$ humate caused $436 \%$ increase compared to the neat handsheet. The bending properties are the function of thickness and the bonding between the cellulose fibres and the fillers [18]. Due to the presence of humate the sheets became thicker which can be the main raison for the higher bending resistance. It can be assumed from the tensile and compressive strength results that the humate could presumably increase the $\mathrm{CuSO}_{4}$ modified fiberfiber connections as well.

Based on the results (as seen in Table 5) the tensile strength and also the strain at break showed lower values for all the samples compared to the sheet prepared from unmodified fibers. Although the TS 2 sample, containing $10 \mathrm{w} \%$ potassium-humate, had the lowest strengths the tensile strength was increased by the humate content. Adding the highest amount (50w \%) of PH increased the tensile strength to $7.8 \mathrm{kN} / \mathrm{m}$ which is comparable to the control sample, where $8.5 \mathrm{kN} / \mathrm{m}$ was obtained. The strain was also improved by the humate compared to the cellulose sheets prepared from $\mathrm{CuSO}_{4}$ modified fibers.

Results of short-span compression test showed (Table 5) the same tendency as bending resistance or tensile test. The potassium-humate induced improvement of compressive strength compared to the acidicaly modified fiber sheet. By increasing the humate content the improvement was 10, 13 and $70 \%$. Compering the TS 4 and TS 1 samples the increase was $5 \%$.

As it is known the mechanical properties are deteriorating by the acidic fiber treatment [19] [20], however, using appropriate amounts of alkali humate the initial mechanical properties of the neat test sheet could be maintained. 


\begin{tabular}{|c|c|c|c|c|c|c|c|}
\hline & $\begin{array}{l}\text { Bending } \\
\text { resistance } \\
(\mathrm{mN})\end{array}$ & $\begin{array}{c}\text { Compressive } \\
\text { strength } \\
(\mathrm{kN} / \mathrm{m})\end{array}$ & $\begin{array}{c}\text { Tensile } \\
\text { strength } \\
(\mathrm{kN} / \mathrm{m})\end{array}$ & $\begin{array}{c}\text { Strain at } \\
\text { break } \\
(\%)\end{array}$ & $\begin{array}{l}\text { Air resistance } \\
\text { (s/100 ml) }\end{array}$ & $\begin{array}{l}\text { Grammage } \\
\left(\mathrm{g} / \mathrm{m}^{2}\right)\end{array}$ & $\begin{array}{l}\text { Thickness } \\
\text { (mm) }\end{array}$ \\
\hline TS 1 & $24.0 \pm 1.7$ & $3.8 \pm 0.6$ & $8.5 \pm 0.3$ & $3.5 \pm 0.2$ & $624.9 \pm 132.4$ & $142 \pm 10$ & $165 \pm 17$ \\
\hline TS 2 & $31.7 \pm 0.6$ & $2.6 \pm 0.5$ & $4.4 \pm 0.2$ & $1.6 \pm 0.1$ & $136.03 \pm 33.1$ & $149 \pm 16$ & $226 \pm 28$ \\
\hline TS 3 & $48.2 \pm 3.5$ & $2.9 \pm 0.3$ & $5.9 \pm 0.1$ & $1.7 \pm 0.1$ & $169.96 \pm 50.5$ & $153 \pm 19$ & $226 \pm 21$ \\
\hline TS 4 & $104.7 \pm 6.1$ & $4.0 \pm 0.5$ & $7.8 \pm 0.4$ & $1.9 \pm 0.3$ & $262.52 \pm 149$ & $249 \pm 21$ & $308 \pm 32$ \\
\hline TS 5 & $29.3 \pm 9.9$ & $2.3 \pm 0.2$ & $5.5 \pm 0.2$ & $1.4 \pm 0.2$ & $120 \pm 62.5$ & $147 \pm 17$ & $171 \pm 22$ \\
\hline
\end{tabular}

\subsection{Air resistance}

The porosity of the sheets containing $\mathrm{CuSO}_{4}$ modified fibers was drastically decreased (Table 5). The enhanced air permeability is presumably due to the partial acidic hydrolysis of the fines and thin fibrils which could decrease the free space between the cellulose fibers in TS 1 . As it can be seen in Table the presence of humate decreased the porosity and compared to TS 5, the test sheets TS 2, TS 3 and TS 4 showed 13, 41 and 117\% decrease, respectively. Handsheet with 50 w\% PH had still 50\% lower air resistance compared to TS 5.

\section{Conclusions}

During our research we prepared potassium-humate and $\mathrm{CuSO}_{4}$ modified linter cellulose sheets to get an overview how the copper sulfate and alkali humate affects the colour, wettability, mechanical and air resistance properties of the hand sheets.

According to the results the humate adsorbed well onto the copper sulfate modified cellulose fiber surface which was shown by the intensive colour difference. The wettability and surface energy was not highly affected by adding copper sulfate or humate to the fibers. Compared to the $\mathrm{CuSO}_{4}$ modified cellulose sheets, humate containing sheets showed slightly lower values which was increased by the humate amount.

The treatment with copper sulfate led to the decrease of the mechanical and air resistance properties of the handsheet. By adding the alkaline humate the mechanical properties were improved in the function of the humate content, the properties became comparable to the control cellulose sheet. With $50 \mathrm{w} \%$ humate content the bending resistance exceeded the resistance of the neat sheet. 
Although, the suitability of copper sulfate and humate modified sheets as active packaging material is needed to be examined, the high air permeability and the unaffected hydrophility can be beneficial at the planned gas and aqueous liquid absorption.

\section{Acknowledgement}

This article was made in frame of the „EFOP-3.6.1-16-2016-00018- Improving the role of research+development+innovation in the higher education through institutional developments assisting intelligent specialization in Sopron and Szombathely".

\section{References}

[1] Dhanapal, S. - Sekar, D. S. - Manasa, P. (2014) Enhancement of antioxidant potential in Musa accuminata using humic acid. International Journal of Agriculture Innovations and Research, 2.4: pp. 429-435.

[2] Dogan, H. - Koral, M., Vatansever A. - Inan, T. - Ziypak, M. - Olgun, Z. - Beker, Ü. (2015) New Method for the Production of Barium Humate from Turkish Coal. Advances in Chemical Engineering and Science, 5.03: 290.

[3] Stevenson F.J. (1992) Comparison of soil humic substances with those of other environments. Humus Chemistry: Genesis, Composition, Reactions, second ed. Wiley, Canada, p. 54.

[4] Erdogan, S. - Baysal, A. - Akba, O. - Hamamci, C. (2007) Interaction of Metals with Humic Acid Isolated from Oxidized Coal. Polish Journal of Environmental Studies. 16 pp. 671-675.

[5] He Zh. - Mao J. - Honeycutt W. - Ohno T. - Hunt J.F. - Cade-Menun B.J. (2008) Spectral Characterization of Plant-Derived Dissolved Organic Matter. Perminova, I.V., Kulikova, N.A., (Eds.) From Molecular Understanding to Innovative Applications of Humic Substances. MGUMUS Publications, Moscow, 2008. pp. 87-91

[6] Tombacz, E. - Dobos, A. - Szekeres, M. D. E. K. A. N. Y., Narres, H. D., Klumpp, E., \& Dekany, I. (2000) Effect of $p H$ and ionic strength on the interaction of humic acid with aluminium oxide. Colloid and Polymer Science. 278(4) pp. 337-345.

[7] Tombacz, E. - Libor, Z. - Illes, E. - Majzik, A. - Klumpp, E. (2004) The role of reactive surface sites and complexation by humic acids in the interaction of clay mineral and iron oxide particles. Organic Geochemistry. 35(3) pp. 257-267.

[8] Kóródi, Gy. (2012) Application of humic acids and their derivatives in environmental pollution control. AARMS. 11 pp. 61-65.

[9] Sun, Z. - Feng, R. - Zhang, L. - Xie, H. (2018) CO 2 capture and sequestration by sodium humate and $\mathrm{Ca}(\mathrm{OH}) 2$ from carbide slag. Research on Chemical Intermediates. 1-15.

[10] Wu, J. - West, L. J. - Stewart, D. I. (2001) Copper (II) humate mobility in kaolinite soil. Engineering geology. 60 (1-4) pp. 275-284.

[11] [Kostić, I. - Anđelković, T. - Nikolić, R. - Bojić, A. - Purenović, M. - Blagojević, S. - Anđelković, D. (2011) Copper (II) and lead (II) complexation by humic acid and humic-like ligands. Journal of the Serbian Chemical Society. 76(9) pp. 1325-1336.

[12] Orosz K (2008) XVI-XVII. Századi festett papírtárgyak vizsgálata és konzerválási lehetöségei, DLA értekezés. Magyar Képzőművészeti Egyetem Doktori Iskola 
[13] Llorens, A. - Lloret, E. - Picouet, P. - Fernandez, A. (2012) Study of the antifungal potential of novel cellulose/copper composites as absorbent materials for fruit juices. International journal of food microbiology. 158(2) pp. 113-119.

[14] Booshehri, A. Y. - Wang, R. - Xu, R. (2015) Simple method of deposition of CuO nanoparticles on a cellulose paper and its antibacterial activity. Chemical Engineering Journal. 262 pp. 999-1008.

[15] Zhao, Y. - Hao, R. - Wang, T. - Yang, C. (2015) Follow-up research for integrative process of preoxidation and post-absorption cleaning flue gas: Absorption of NO2, NO and SO2. Chemical Engineering Journal. 273 pp. 55-65.

[16] Straže, A. - Gorišek, Ž. - Pervan, S. - Prekrat, S. - Antonović, A. (2008) Research on colour variation of steamed cherrywood (Prunus avium L.). Wood Research. 53(2) pp. 77-90.

[17] Jirouš, R. V. - Ljuljka, B. (1999) Boja drva i njezine promjene prilikom izlaganja atmosferskim utjecajima. Drvna industrija. 50(1) pp. 31-39.

[18] Wan, C. - Jiao, Y. - Li, J. (2017) Flexible, highly conductive, and free-standing reduced graphene oxide/polypyrrole/cellulose hybrid papers for supercapacitor electrodes. Journal of Materials Chemistry A. 5(8) pp. 3819-3831.

[19] Cowan, W. F. (1995) Explaining handsheet tensile and tear in terms of fiber-quality numbers. Tappi journal.--(USA).

[20] Badve, M. P. - Gogate, P. R. - Pandit, A. B. - Csoka, L. (2014) Hydrodynamic cavitation as a novel approach for delignification of wheat straw for paper manufacturing. Ultrasonics

[21] Lukács Gy. (1982) Színmérés. Műszaki Kiadó, Budapest, 341. p

[22] Steele, D. F. - Moreton, R. C. - Staniforth, J. N. - Young, P. M. - Tobyn, M. J. - Edge, S. (2008) Surface energy of microcrystalline cellulose determined by capillary intrusion and inverse gas chromatography. The AAPS journal. 10(3) pp. 494-503.

[23] Cummins G - Desmulliez MPY (2012) Inkjet printing of conductive materials: a review. Circuit World. 38 pp. 193-213

[24] MSZ EN ISO 5267-1:2000 Cellulózok. Az őrlésfok meghatározása. 1. rész: Schopper-Rieglermódszer (ISO 5267-1:1999)Pulps - Determination of drainability -Part 1: Schopper-Riegler method, MSZH, Budapest, 2000

[25] MSZ EN ISO 536:2013 Papír és karton. A négyzetmétertömeg meghatározása (ISO 536:2012) (Paper and board. Determination of grammage (ISO 536:2012)), MSZH, Budapest, 2013

[26] MSZ ISO 5636-1:1993 Papír és karton. A légáteresztő képesség meghatározása (közepes tartományban). Általános módszer, Paper and board. Determination of air permeance (medium range). Part 1: General method, MSZH, Budapest, 1993

[27] HU 209134 Eljárás huminsav-alkálisót tartalmazó kolloid oldatok előállítására, 1991.január 11, Szellemi Tulajdon Nemzeti Hivata, Budapest

[28] HU 207682 A : Eljárás növelt adszorpcióképességú cellulózbázisú csomagolóanyagok előállítására, 1991.április 17. Szellemi Tulajdon Nemzeti Hivatal, Budapest 